inOedia $\quad \begin{aligned} & \text { InMedia } \\ & \text { The French Journal of Media Studies }\end{aligned}$

7.2. $\mid 2019$

Documentary and Entertainment

Immigrant Rights Documentaries and Engagement

Eliciting Emotion to Counter the Latino Threat Narrative

Emilie Cheyroux

(2) OpenEdition

Journals

Electronic version

URL: http://journals.openedition.org/inmedia/1718

DOI: 10.4000/inmedia.1718

ISSN: 2259-4728

Publisher

Center for Research on the English-Speaking World (CREW)

Printed version

Date of publication: 15 December 2019

Electronic reference

Emilie Cheyroux, "Immigrant Rights Documentaries and Engagement", InMedia [Online], 7.2. I 2019,

Online since 15 December 2019, connection on 26 January 2021. URL: http://

journals.openedition.org/inmedia/1718; DOI: https://doi.org/10.4000/inmedia.1718

This text was automatically generated on 26 January 2021.

(C) InMedia 


\title{
Immigrant Rights Documentaries and Engagement
}

\author{
Eliciting Emotion to Counter the Latino Threat Narrative
}

\section{Emilie Cheyroux}

\section{Introduction}

1 According to Leo R. Chavez, Latino immigrants suffer from the "Latino Threat Narrative," which portrays them as "aliens" coming to invade the United States. ${ }^{1} \mathrm{He}$ explains that the narrative started gaining momentum in the 1920s, when the term "illegal alien" was coined, and that since then, the argument of "illegality" has been used to classify Latinos as undesirable immigrants. ${ }^{2}$ The Latino Threat Narrative includes the beliefs that Latinos do not want to speak English, that they will not integrate socially and culturally, that Mexican immigrants have the ultimate plan to reconquer the land that was annexed by the United States after the Mexican-American War (1846-1848) $)^{3}$ and, finally, that Latinas give birth to "anchor babies" that will upend demographics and make way for the alleged "reconquista." This last belief fuels the metaphor of the "invasion" or "infestation" that the most conservative figures have integrated in their rhetoric. For instance, in 2019, Tucker Carlson, in his show Tucker Carlson Tonight, (Fox News, 2016-present) has argued that immigrants made the United States "poorer and dirtier." ${ }^{4}$ Chavez, through the use of data about the reproduction rates of Latinas as well as Latino kids' social and linguistic habits in Orange County, undermines the belief of an uncontrolled population that will not assimilate. On the contrary, Chavez demonstrates that it is the lack of immigration status that represents "the biggest obstacle to more rapid economic integration." ${ }^{5}$ His analysis invites the reader to consider the singularity of Latinos in the history of immigration, whose share of the foreign-born population has grown steadily since the 1960s, with Mexican and other Latin American immigrants each making up about a quarter of the U.S. immigrant population (about 11.7 million Mexicans and 10.4 million Latin Americans in 2015), ${ }^{6}$ adding to the existing US-born Latino population (37.5 million in 2015). ${ }^{7}$ 
2 Since the late 1970s and particularly at the turn of the twenty-first century, a growing number of documentary films dealing with unauthorized immigration have attempted to show the economic, political, ideological, and humanitarian causes surrounding the issue. ${ }^{8}$ Anne Teresa Demo, who describes them as the "emerging genre" of Immigrant Rights Documentaries, explains that the most recent ones tend to "decriminalize unauthorized immigration," inviting the viewers to reconsider the reasons why people immigrate..$^{9}$ Portraying immigrants in a compassionate way and studying immigration from different perspectives, these documentaries can influence the debate over immigration reforms, such as the offer of amnesty for undocumented immigrants that both Presidents George W. Bush and Barack Obama asked Congress to pass. An overwhelming majority of these films focus on Latino immigrants and obscure the others. Due to the fact that recent documentaries, such as The Infiltrators (Cristina Ibarra and Alex Rivera, 2019) shed light on other immigrants (Iranian, Congolese, Chinese), this article will use the term Latino Immigrant Rights Documentaries.

While the Latino Threat Narrative elicit emotions such as fear, anxiety, and anger, the Latino Immigrant Rights Documentaries use pity, compassion, or sympathy. This article posits that these documentaries have the potential to counteract the Latino Threat Narrative, and involve the viewers in a way that resonates with Carl Plantinga's "engagement theory" that places emotion at the heart of the relationship between the viewer and what he calls the "stories on screen." ${ }^{10}$ But when it comes to reception, this study strives to keep in mind David J. Cisneros' cautionary approach about the longterm impact of such documentaries. ${ }^{11}$ By identifying the "emotional habitus" of the American population as being entrenched in emotions such as fear and anxiety towards immigrants, Cisneros warns that emotions "circulate and become sedimented" in society so much that they "ground ideologies" that are not easily modified or replaced. ${ }^{12}$ Thus, this article focuses on the way Immigrant Rights Documentaries deconstruct the thought that Latinos are a threat to the United States and evoke an emotional reaction likely to "disrupt or redirect affects" towards immigrants. ${ }^{13}$

4 Four documentaries released in the United States during the years leading up to Obama's election are scrutinized: Al Otro Lado (Natalia Almada, 2005), Crossing Arizona (Dan DeVivo and Joseph Mathew, 2006), La Americana (Nicholas Bruckman, 2008), and Point of Entry (Zeus Quijano Jr, 2009). ${ }^{14}$ They show the diverse situations that motivate migration to the United States. La Americana tells the story of a Bolivian mother who immigrated to save money in order to pay for her tetraplegic daughter's medical needs. Point of Entry focuses on a Mexican immigrant, Carlos, who immigrated to offer a better future to and provide for his family on both sides of the border. Al Otro Lado and Crossing Arizona both focus on border crossings and contain numerous testimonials from different people (migrants, Border Patrol agents, local residents, humanitarian associations, and vigilante groups). All of them also highlight the economic and geopolitical reasons that affect Latin Americans and explain migration, as opposed to the Latino Threat Narrative, which focuses on a discourse asserting that Latino immigrants "steal jobs" from the American people. On the contrary, Chavez advocates for a "Latino contribution narrative" that resonates with the stories portrayed by these four Latino Immigrant Rights Documentaries. ${ }^{15}$ 


\section{Documentary films, emotion and engagement theory}

5 Documentary filmmakers set out to "persuade and convince" the viewers of a particular view on the world, hoping that their film will enlighten them and lead to behavioral changes. ${ }^{16}$ One of the elements Weik von Mossner singles out as a powerful tool to engross the viewer is the emotional appeal of documentaries. ${ }^{17}$ While suggesting that documentaries have the power to harness emotions is neither ground-breaking nor new, the strong link between affective and cognitive processes behind the eliciting of an emotion brings to light the way the viewers can engage in a film. Being both a bodily feeling (commonly termed affect) and a cognitive reaction (a conscious rational process), emotion is part of a two-fold process that, according to Weik von Mossner, is "fundamental to what makes film artistically, rhetorically powerful, and culturally influential." ${ }^{18}$ Her research draws on Plantinga's "engagement theory," which considers that an emotional reaction is the first step to ethical engagement that has cognitive consequences likely to influence the viewers. For, as Michael Chanan explains, documentaries address the viewer "as a citizen, member of civil society, putative participant in the public sphere" and thus, have the potential to call into question his or her own civic engagement in society. ${ }^{19}$ The study of the power of film is thus particularly fruitful to highlight how the Immigrant Rights Documentaries can "immerse" the viewers in a story so that they might have moral responses to the immigrants. ${ }^{20}$

On this particular topic, the similarities between documentaries and fiction films are worth considering in more detail. Nichols argues that documentaries are "fictions with plots, characters, situations, and events," and also that they also offer "introductory lacks, challenges, or dilemmas." ${ }^{21}$ With their "conflict-driven" plots and the wide range of "charter-type" people that they involve, the Immigrant Rights Documentaries confirm that definition. ${ }^{22}$ Since they expose the challenges that the immigrants meet when they cross the border and highlight the dilemmas they face when they leave their families behind, they capitalize on the dramatization inherent to plots involving a survival dilemma. But as Weik von Mossner point outs, in documentaries the viewer is not faced with actors but with "the faces and voices of human beings" who evolve in a "concrete environment." ${ }^{23}$ Therefore, identification to and sympathy for these people can become crucial tools to evoke strong emotions. Carmen's story in La Americana is a good example of a situation that has a high potential for compassion. Because she is undocumented, she hesitates to go back to Bolivia to visit her daughter because then, she will have to be smuggled back into the U.S. again, but if she stays with her daughter, she will not be able to afford the expensive medical treatment that she needs to treat her. What characterizes her situation and numerous Latino Immigrant Rights Documentaries is the lack of resolution inherent to the legal situation of the immigrants, which, in this particular movie, is highlighted by the fact that Carmen's hopes of seeing George W. Bush's Comprehensive Immigration Reform Act of 2007 pass Congress vanish towards the end of the film..$^{24}$ What matters nevertheless, more than her Catch-22 situation, is the way the filmmaker films her and her environment in order to cue emotions. The following part will thus focus on the emotional techniques at play in La Americana, as well as in Point of Entry, two documentaries that focus on an individual's situation and stress their emotional state of mind. 


\section{Straight-to-camera testimonies, re-enacted emotions and pathetic fallacy: La Americana and Point of Entry}

7 In La Americana and Point of Entry, a few elements suggest that the filmmakers spent a significant amount of time with the immigrants, during which they also accompanied them to their home country - Bolivia and Mexico. This extended amount of time spent on location during, or before, the production of the documentary not only guarantees better knowledge of the situation, it also provides more opportunities to witness an important event or a highly emotional moment. This "caught-on-camera" footage is paramount to harness emotions, especially when it captures intimate moments shared between family members. ${ }^{25}$ In La Americana, the scene during which Carmen reunites with her daughter to attend her quinceañera ${ }^{26}$ birthday party is particularly powerful and elicits a wide range of emotions that probably echo Carmen's. She is happy and, at the same time, we can assume that she might also be sad, disappointed and worried to be back in Bolivia before she could save enough money. We thus cannot help but wonder if she will return to the United States, leave her daughter behind, and endanger her life again.

But the scenes that are most likely to evoke strong emotions are the ones during which the immigrants testify while looking directly into the camera. This technique, used in both documentaries, is very efficient for it creates intimacy between the viewers and the immigrant (or their family). In La Americana, Nicholas Bruckman interviews Carmen in four different locations, the most important of which is the Statue of Liberty. Sitting in front of the camera with the New York City skyline in the background (Figure 1), Carmen explains that it was never her dream to go to the United States but that she had no alternative. As in all of her straight-to-camera testimonies, she is moved to tears and stresses her sacrifice that she universalizes to the numerous undocumented immigrants who work in the U.S.: "Tienes que mentir y tienes que caminar, $y$ tienes que arriesgar tu vida para poder cruzar y llegar a este lugar. Tienes que endeudarte. Tienes que lejarte de todo tu familia, de todas las cosas que quieres, de tu casa, de tus cosas, de tus animales, de tus hijos, de tu madre." ${ }^{27}$ Carmen's testimony thus corresponds to "the melodramatic story of self-sacrifice" that Plantinga identifies, which generates pity then admiration. ${ }^{28}$ She is portrayed as a hero, whose resilience and devotion to her child also stirs empathy in the viewers. They are then likely to share her emotions and agree with her when she says that she's "not a threat to anyone," counteracting the demonization inherent to the Latino Threat Narrative.

The scene at the Statue of Liberty takes on additional meaning because of the symbol of the monument. With close-ups of the information provided to tourists, Bruckman reminds the viewers that The New Colossus (Emma Lazarus, 1883), the poem on the bronze plaque situated on the statue's pedestal, is a welcoming message for the "poor" and "tired" immigrants. ${ }^{29}$ The viewers are thus enticed to associate Carmen with the verses and sympathize with her. Drawing on Jonathan Haidt's research, Plantinga reminds us that there are four families of emotions (other-condemning, other-praising, self-conscious, and other-suffering). ${ }^{30}$ While most straight-to-camera testimonies tap into Carmen's suffering, in this particular scene, the filmmaker's use of the symbol of the Statue of Liberty is supposed to elicit self-conscious emotions in the viewers. The film's primary audience being American, it is meant to create an "ethical dilemma" ${ }^{1}$, whose goal is to appeal to the moral principles of the viewers when they understand, as 
Carmen says, that the Statue is "just a symbol" (Figure 1) because immigrants like her are not welcome. Her situation appears unfair because the documentary repeatedly shows that she is a hard worker who takes English classes, and therefore, that she does her best to assimilate into American society (even if her stay is temporary). Additionally, Carmen visits the Statue of Liberty right before going back to Bolivia, not on arrival as did the former generation of immigrants, apparently symbolizing the failure of the message.

Figure 1: Carmen visits the Statue of Liberty before going back to Bolivia
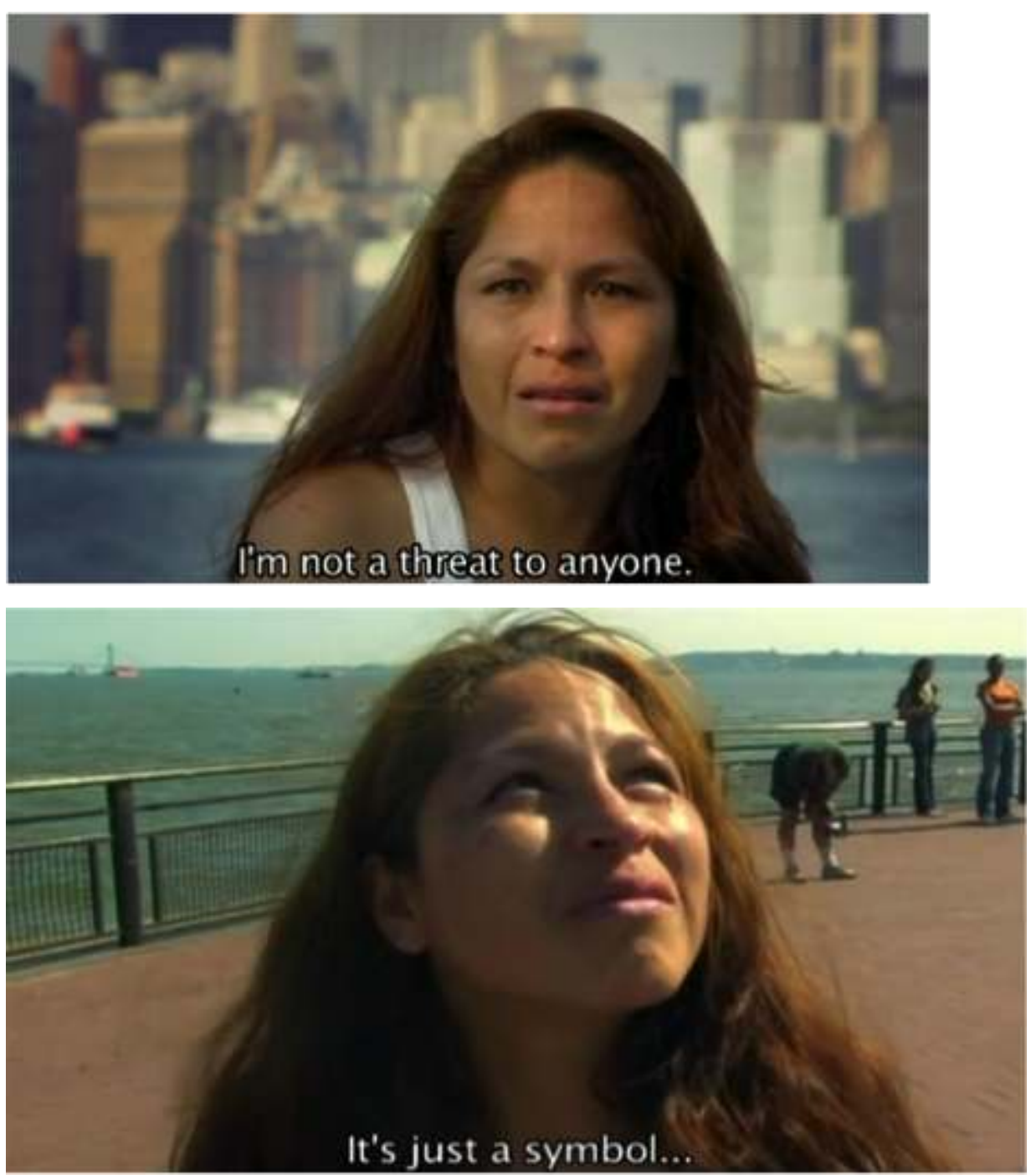

La Americana (Nicholas Bruckman, 2008), screen captures.

10 Carlos, in Point of Entry, also delivers a story of self-sacrifice: he immigrated to the United States when he was fifteen and has since then worked hard to provide for his parents and brothers in Mexico, and for his wife and children who live with him in California. On each side of the border, Zeus Quijano Jr. has all the family members speak directly to the camera (Figure 2). While most of them keep their composure, Carlos's mother bursts out crying. Dezheng Feng and Kay L. O'Halloran's research shines an interesting light on the chain of events that led to this outburst. According to them, an Eliciting Condition (EC) engenders a Feeling State (FS) that leads to its 
Expression (Ex). ${ }^{32}$ During the testimonies, the feeling (FS) and the expression (Ex) have already been experienced. One can assume for instance that Carlos' mother's reaction was the same when her son left. The purpose of the interview then is to create the conditions that will have her go through the emotion again (EC). In such a process, what matters is the "emotional antecedent" and the persistence of the traumatic feeling to create pathos likely to have the viewers identify with their plight. ${ }^{33}$

Figure 2: Carlos and his family's straight-to-camera testimonies
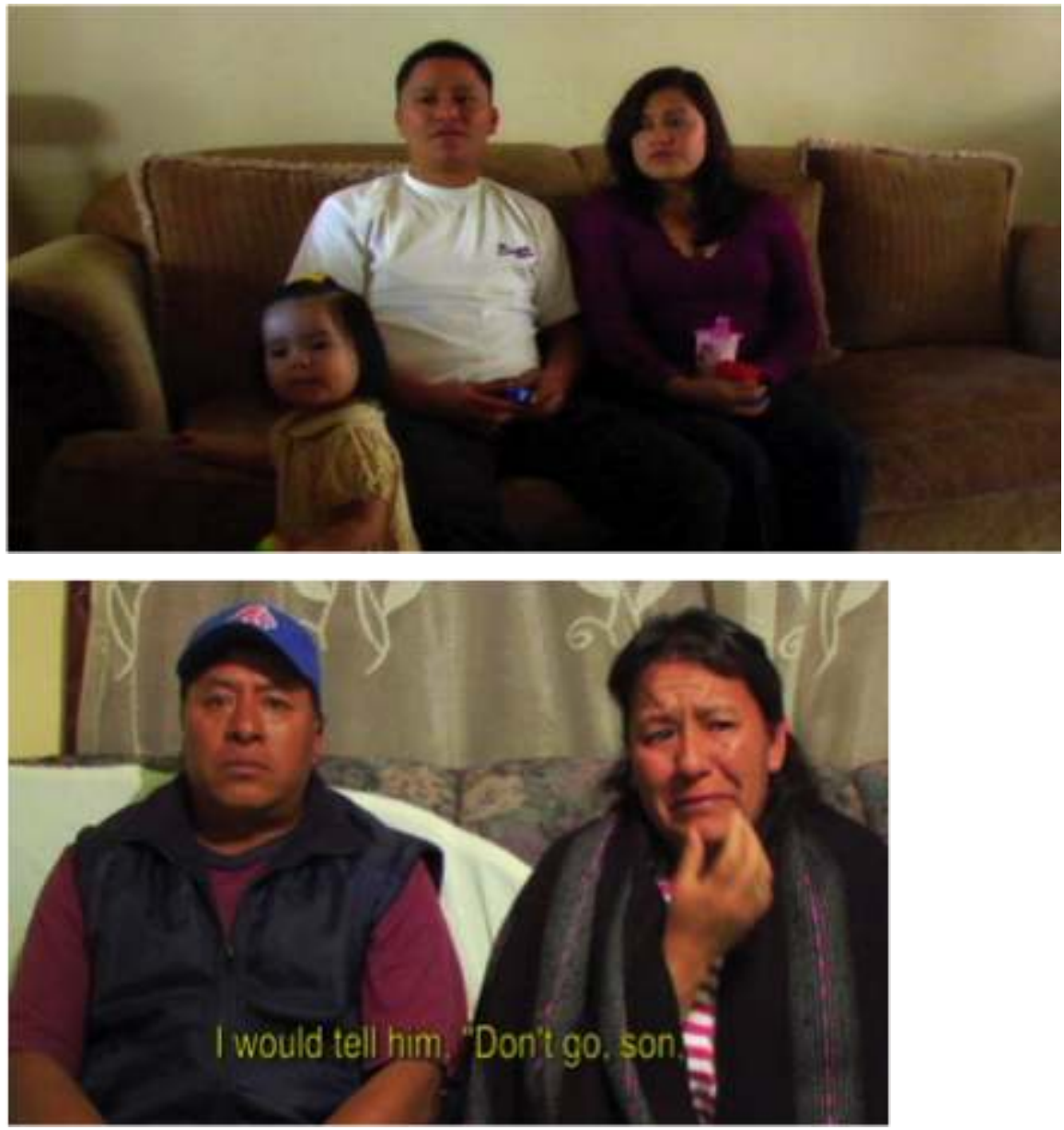

Point of Entry (Zeus Quijano Jr, 2009); screen captures.

11 Even though Carlos always remains calm, it does not mean that his emotions have no effect. During a great part of the film, his testimony is featured thanks to a voice-over, whose sadness indicates that he is suffering from the separation from his family. At the beginning of the film, a sequence shows him driving with a sunset in the background while, in an almost flawless English, he expresses his concern that something might happen to his parents one day, and that he might have to cross the border without authorization again. At some point, the profile close-up and the sunset are superimposed for a few seconds, emphasizing the thoughtful state in which he is (Figure 3). It is not the only time that nature is used to convey Carlos' state of mind. This technique reminds the public of the pathetic fallacy usually used in novels and highlights the way long shots of nature might bolster the emotional content of a scene. In La Americana, the same technique is used to indicate that Carmen faces obstacles in Bolivia. Bruckman inserts a long shot of the Cristo de La Concordia statue that 
overlooks her town (Cochabamba) while a storm is brewing and dark clouds are moving across the sky, indicating that her fears of running out of money came true (Figure 3).

The pathos is nevertheless counterbalanced by more positive emotions, which according to Weik von Mossner is essential not to overwhelm the audience. ${ }^{34}$ For instance, in Point of Entry, a scene featuring Carlos' parents shows them teasing each other and laughing. Carlos' father, who had remained silent up to that moment, acknowledges that he is happy to be able to manage a successful grocery shop, and we are meant to guess that Carlos' remittances have played a major role. Such a stealthy statement shows that Carlos' immigration to the United States did improve his family's living conditions.

13 Towards the end of the film, another sunset shows a shooting star right before Carlos expresses his dream that his family "be allowed to come to the United States." This hope might be the filmmakers' too, for Plantinga suggests that the interviews with "likeable people" are "proxies for the perspective of the filmmaker." ${ }^{35}$ When they portray harmless, devoted, and hard-working immigrants, Bruckman and Quijano actually fuel the Latino Contribution Narrative that Chavez advocates for: these immigrants prove to be morally respectable individuals who try to pursue the American Dream, not reconquer lost lands. In La Americana, Bruckman shows Carmen participating in the Bolivian carnival in Queens. A lingering profile shot shows two other participants, one holding the Bolivian flag and another holding the American flag. According to Chavez, who wrote about the controversies that happened during the immigrant protests of 2006, Carmen voices a desire for inclusion because, according to her, being born in the American continent, and being an immigrant, she is truly American..$^{36}$ By naming his documentary "La Americana" (The American), Bruckman reminds the audience of U.S. immigration history and points out the contradictions in the treatment of the current immigrants.

14 Additionally, similarly to what Point of Entry does, the film spotlights the economic absurdity inherent to the situation, using the "logically compelling arguments" of the push and pull factors. ${ }^{37}$ They seem to be saying that if immigrants need jobs and the U.S. needs immigrants, offering them a way to legally travel back and forth would not only be safer for them, but it would entice them to stay temporarily. A few Latino Immigrant Rights Documentaries indeed use the term "migrant" and not "immigrant," such as Casa del Migrante (Marcela Moran, 2006), which deals with the shelters that help the migrants on their way to the U.S. Both Carlos and Carmen insist that their migration is first and foremost economic. Although these two documentaries have chosen to focus on the emotional content, others, such as Al Otro Lado and Crossing Arizona, look deeper into the economic issues that have caused unauthorized immigration, and attempt to appeal to the viewers' rational thinking. What makes them interesting is that they feature testimonies from people who believe in the Latino Threat Narrative. The next part thus attempts to understand how anti-immigration sentiment is demonized. 
Figure 3: Pathetic fallacy in Point of Entry and La Americana
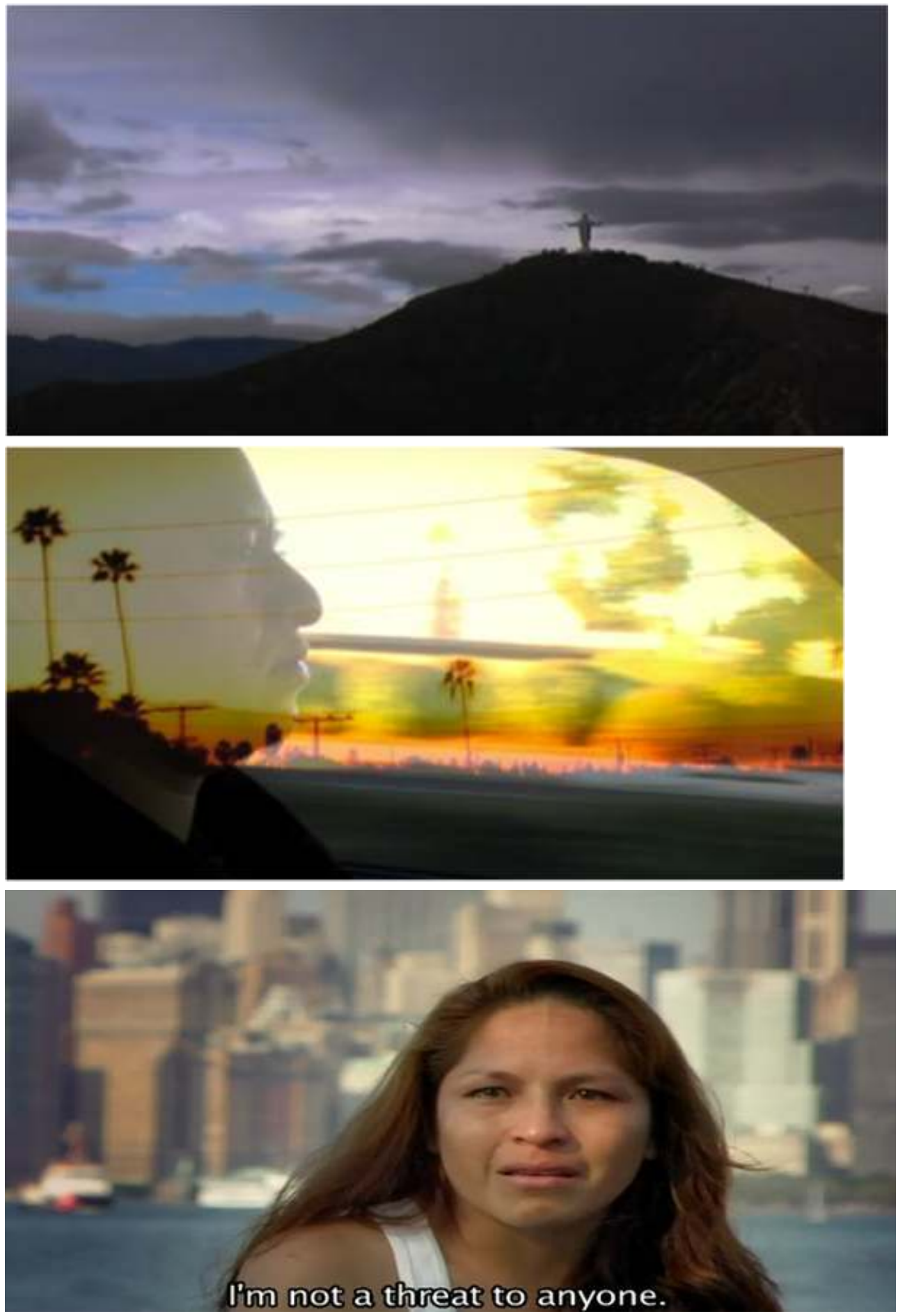

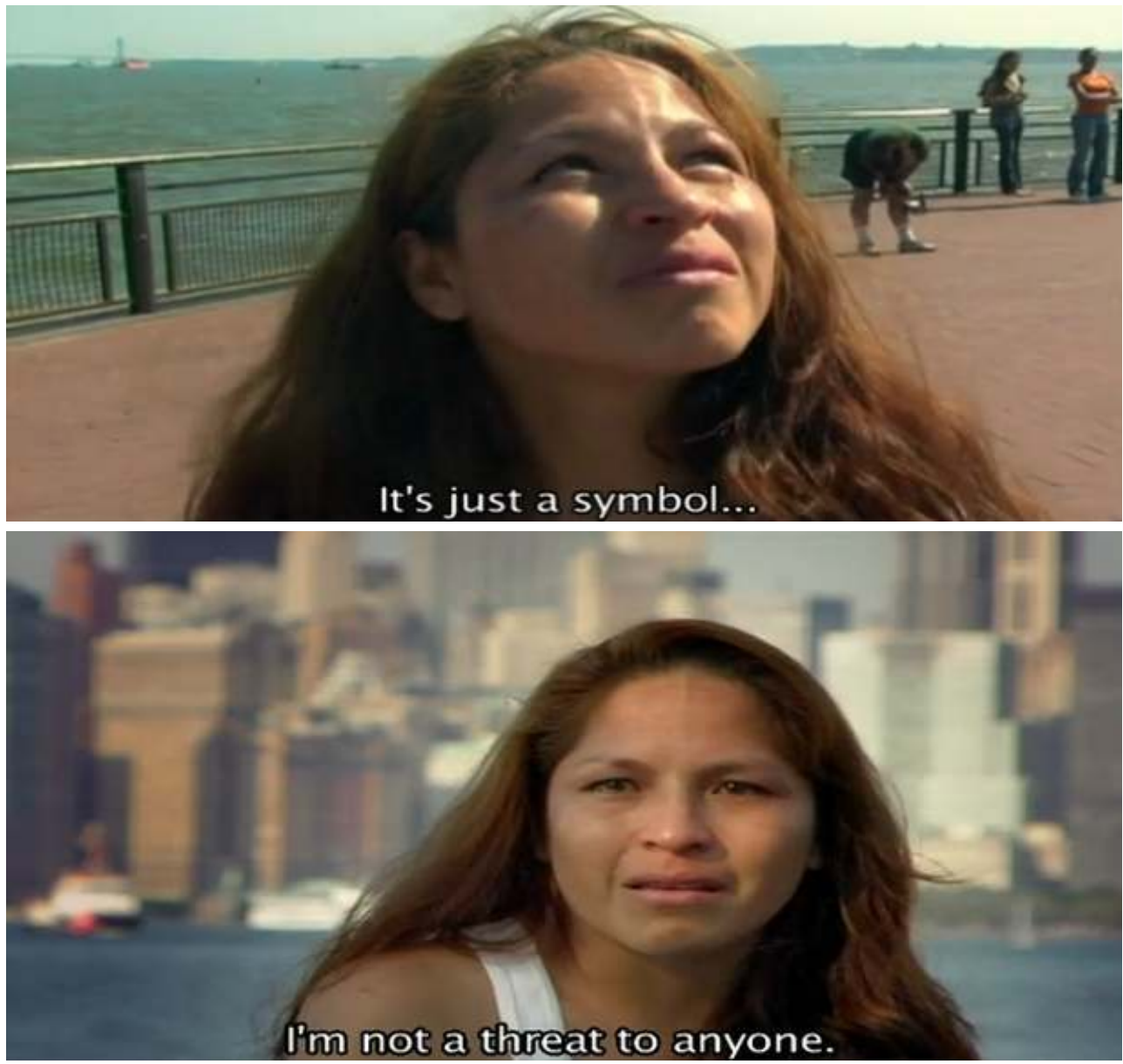

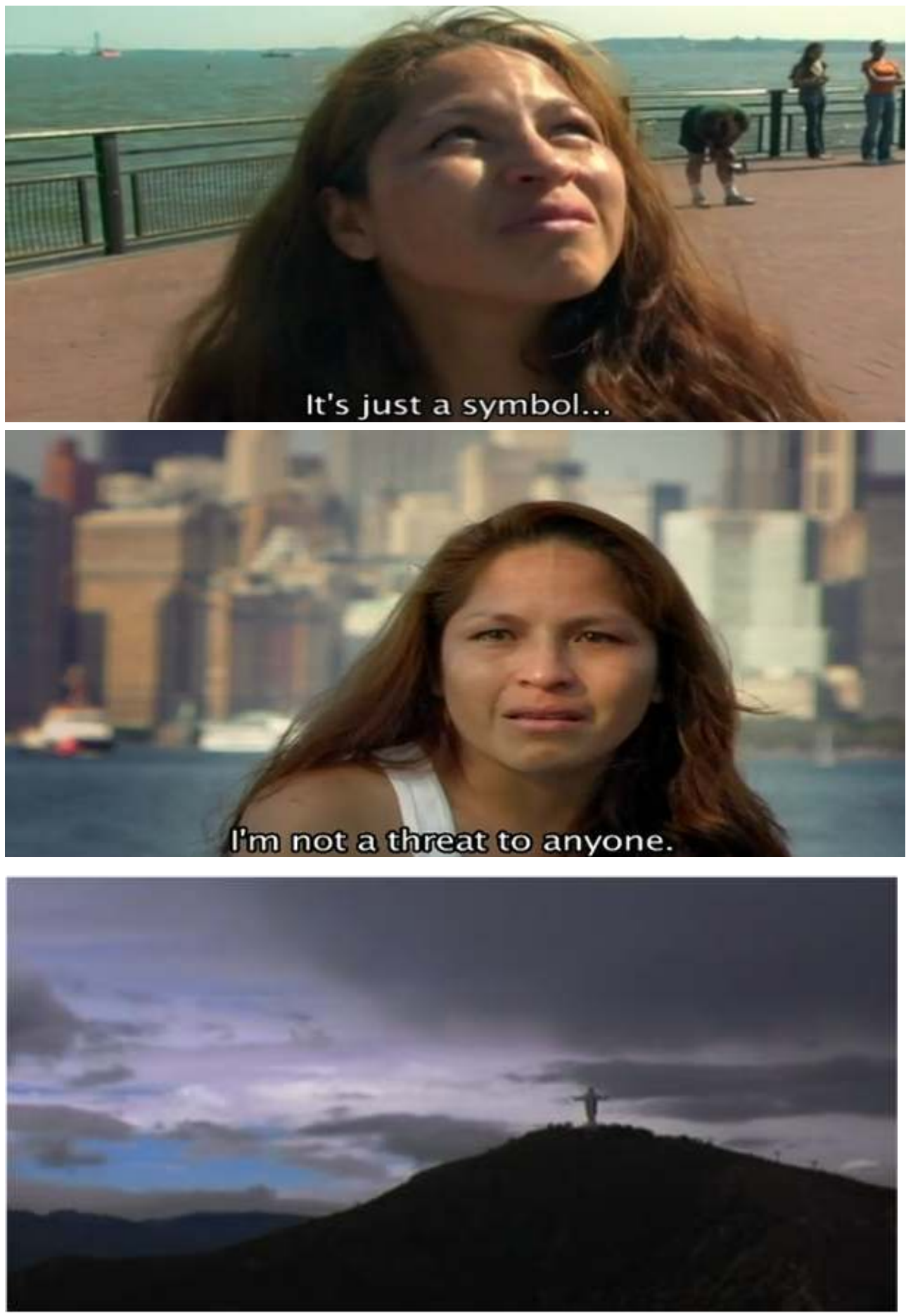

Point of Entry (Zeus Quijano Jr, 2009); La Americana (Nicholas Bruckman, 2008); screen captures.

\section{Moral judgment, reverse demonization and economic realities: Al Otro Lado and Crossing Arizona}

15 When she describes the characteristics of the Immigrant Rights Documentaries, Anne Teresa Demo identifies different categories of "characters." ${ }^{38}$ There are the immigrants, the "Alienated Anglos," who are the primary antagonists, and the "ambivalent lawmen," in other words, the official law enforcement agents. ${ }^{39}$ In Crossing Arizona, even 
more people testify, which creates a polyphony of opinions. Within the first fifteen minutes of the documentary, numerous people testify: an author, a legal counselor, a local Mexican inhabitant, the mayor of the city of Douglas, two Humane Borders activists, and a Border patrol agent. This polyphony allows the viewers to get as much information as possible and view the issue from cultural, economic, humanitarian, and geopolitical perspectives so that they can eventually form what the film implies is an informed opinion. Nevertheless, the emotional content of the documentary is oriented in such a way as to demonstrate that the immigrants are the victims.

Disgust and shock are powerful tools to elicit visceral reactions in the viewers. The images of the immigrants' blistered feet, bones in the desert, decomposed bodies, and even a cemetery of "John Does" inform the viewer of the dangers immigrants face while crossing the desert. Yet the most cogent scene involves a Border Patrol agent showing the picture of a naked pregnant lady who passed away after being abandoned by the smuggler - commonly referred to as a "coyote" - who was supposed to accompany her. The portrayal of the Border Patrol agent is interesting: even though his job is to arrest the "illegal" immigrants who cross the border, he is not the central antagonist. He even expresses deep sadness about the pregnant woman: "It changes you; you never get used to recovering a body in the desert ever [...] That still bothers me to this day because the coyote left her." Both in Crossing Arizona and Al Otro Lado, in keeping with Demo's characterization, the border agents are portrayed as "ambivalent lawmen" who do their job but who are overwhelmed by a situation that saddens them, for the penultimate shot in Crossing Arizona indicates that there have been more than 4,000 deaths in the previous eleven years.

The people most portrayed as untrustworthy and who have much more screen time than the "ambivalent lawmen," are the "alienated Anglos" because the purpose of such films is to "reverse the binary that defines the conventional immigrant coverage" and portray the actions of these antagonists as the truly unlawful acts. ${ }^{40}$ The immigrants can then be presented as victims of people whose actions have often been deemed unsuccessful by the Border Patrol Tucson's sector agents themselves. ${ }^{41}$ The main representative is Chris Simcox, who testifies in Crossing Arizona and Al Otro Lado. Simcox was, at the time of the documentaries, a member of the Minutemen, a surveillance group founded in 2004 by Jim Gilchrist. According to Chavez, they have two goals: patrol the border to arrest migrants and create a spectacle to draw the attention of the federal government. ${ }^{42}$ The demonization technique used by the filmmaker consists in using close-ups of Simcox's irritated facial expression, and lingering on him while he delivers speeches that show his belief in the Latino Threat Narrative:

I can take you to trails when immigrants walk right through this town on a daily basis, and we're 40 miles north of the border. (...) I can take you to some areas that would just disgust you. You should see what's left of this invasion. Ranchers have just given up. They can't even file insurance claims on cut fences and broken-down fences anymore. We've got drug dealers and they just shoot people's cattle for fun, and shoot up people's homes. And then there's the trash that's left behind. ${ }^{43}$

Simcox's speech can be directly linked to the narrative of the "reconquista" in which immigrants are portrayed as invaders. ${ }^{44}$ While the trash left in Arizona is certainly a nuisance, it does not prove that the immigrants wish to invade the U.S., nor that they are necessarily drug dealers. His speech is made to appear clouded by hatred, especially when he disdainfully calls them "these folks," or "amigos," with a derogatory accent. 

He strives to show that he is a good American citizen because he respects the law, while immigrants are criminals because they cross the border without authorization, and litter. While this statement seems perfectly logical, the filmmakers highlight the ethical difference between what is legal and what is morally right, comparing Simcox's behavior with that of the activists of the Humane borders-Frontera Compasiva association, who distribute water in the desert. These "humane Americans," are also portrayed as law-abiding citizens. They represent an additional category that can be added to the typology developed by Demo, which portrays characters as either heroes or villains, feeding a narrative of entertainment. In Crossing Arizona, they are represented by Mike Wilson who coldly tells a migrant looking for help that he can only give him water and information because the law forbids him from transporting unauthorized migrants. During his testimony, he emphasizes the humanitarian logic of his acts ("Can we save a few humans?") because, according to him, whether there is water or not, there will always be migrants risking their lives and, thus, he has to try to reduce the number of deaths.

The documentaries oppose two visions of what civic duty is. While Simcox argues that it is his civic duty to arrest migrants because they take part in "illegal activities," Wilson exemplifies a civic duty based on helping less privileged people. It is this divide - privileged and less privileged - that Al Otro Lado builds on during a scene featuring the arrest of migrants by the Minutemen. Natalia Almada draws on compassion and pity for the migrants and, with the proximity that she has with them during the interview, stresses the distance with the Minutemen. The migrant she talks to is sitting on the ground and whispers his testimony, probably intimidated by the situation (Figure 4). On the verge of crying, he explains that he worked in the fields in Mexico in difficult conditions. A close-up of his blistered hands authenticates his testimony but, after eavesdropping on the conversation, Simcox immediately replies that he rejects the narrative according to which migrants came to the U.S. in order to work. In broken Spanish and a tone that translates his frustration, he rejects the narrative that they have problems to obtain papers, and highlights illegality: “Same story they can't find work in Mexico. They came to work here. And I wish we had a way for them to come legally, and work but "no más illegal'." The camera uses a low-angle shot of him, which suggests his power over the migrants. With this particular mise-en-scène, the documentary conveys the lack of empathy of the Minutemen, who earlier in the movies were happy to go on their mission to catch migrants and "kick some ass." As Plantinga explains, in these kinds of scenes, the filmmaker "cue[s] spectators to judge" which character is "ethically virtuous or lacking or condemnable." ${ }^{45}$ Simcox, with his disdainful attitude, is the condemnable character. The alleged danger of the migrants is debunked and the demonization is reversed to portray the Minutemen as the "morally reprehensible and unlawful." ${ }^{46}$ 
Figure 4: Chris Simcox and the Minutemen arrest migrants

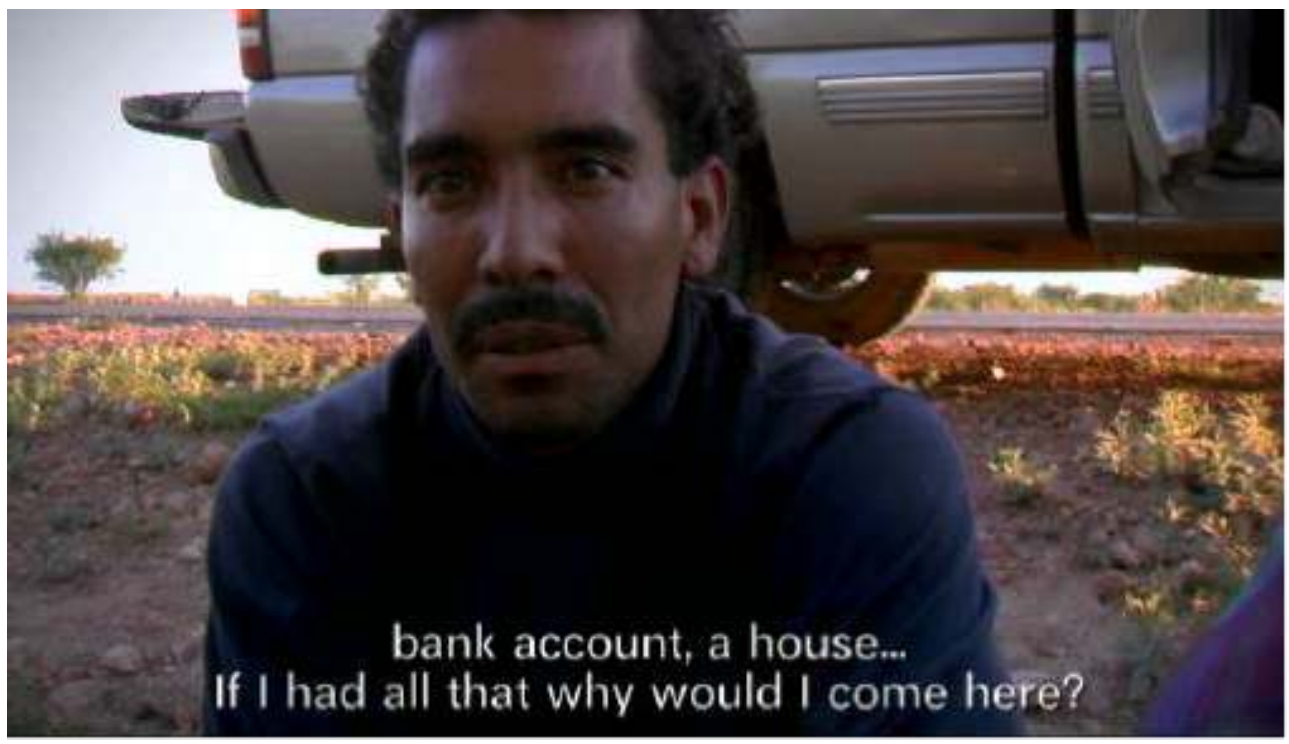



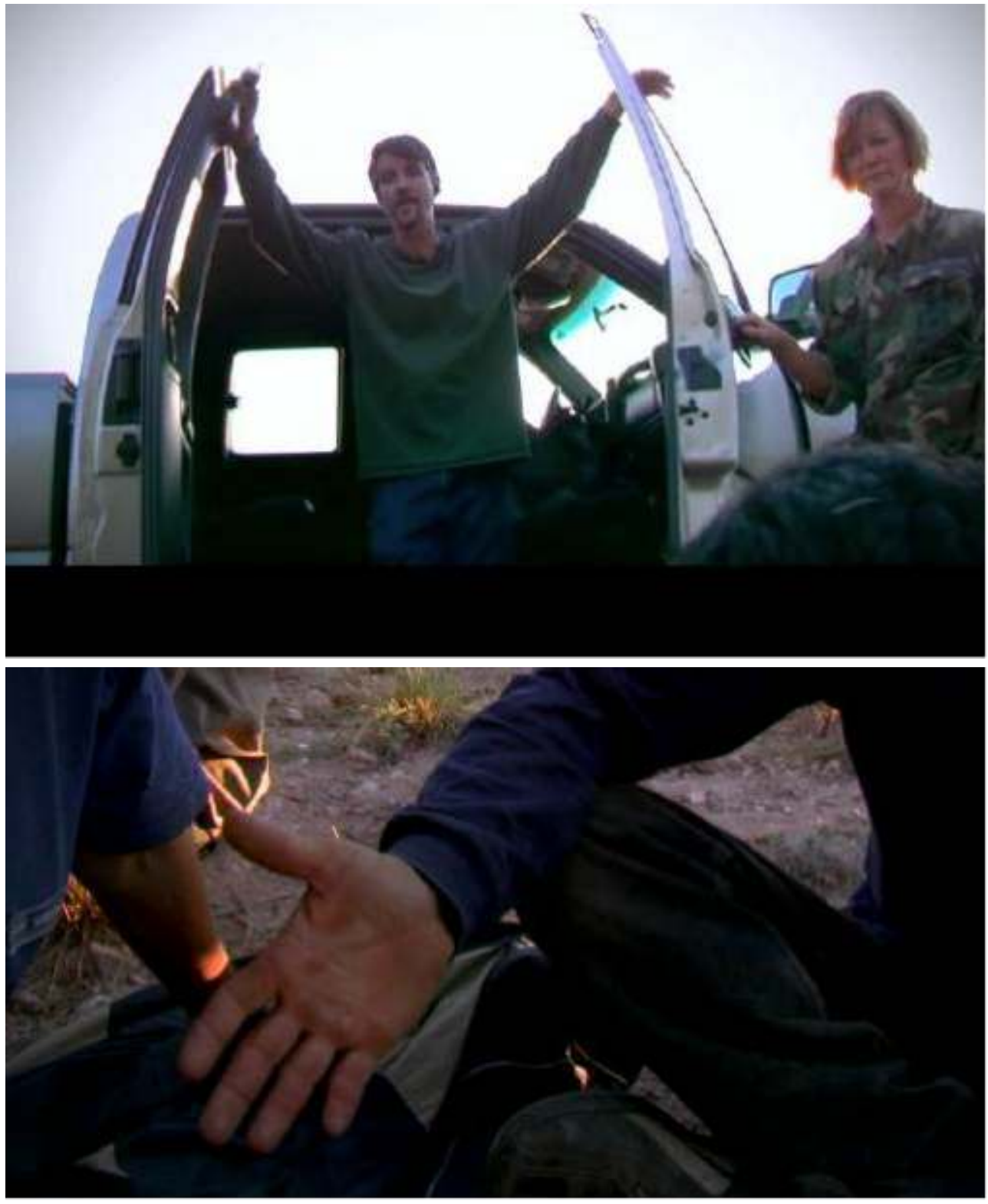


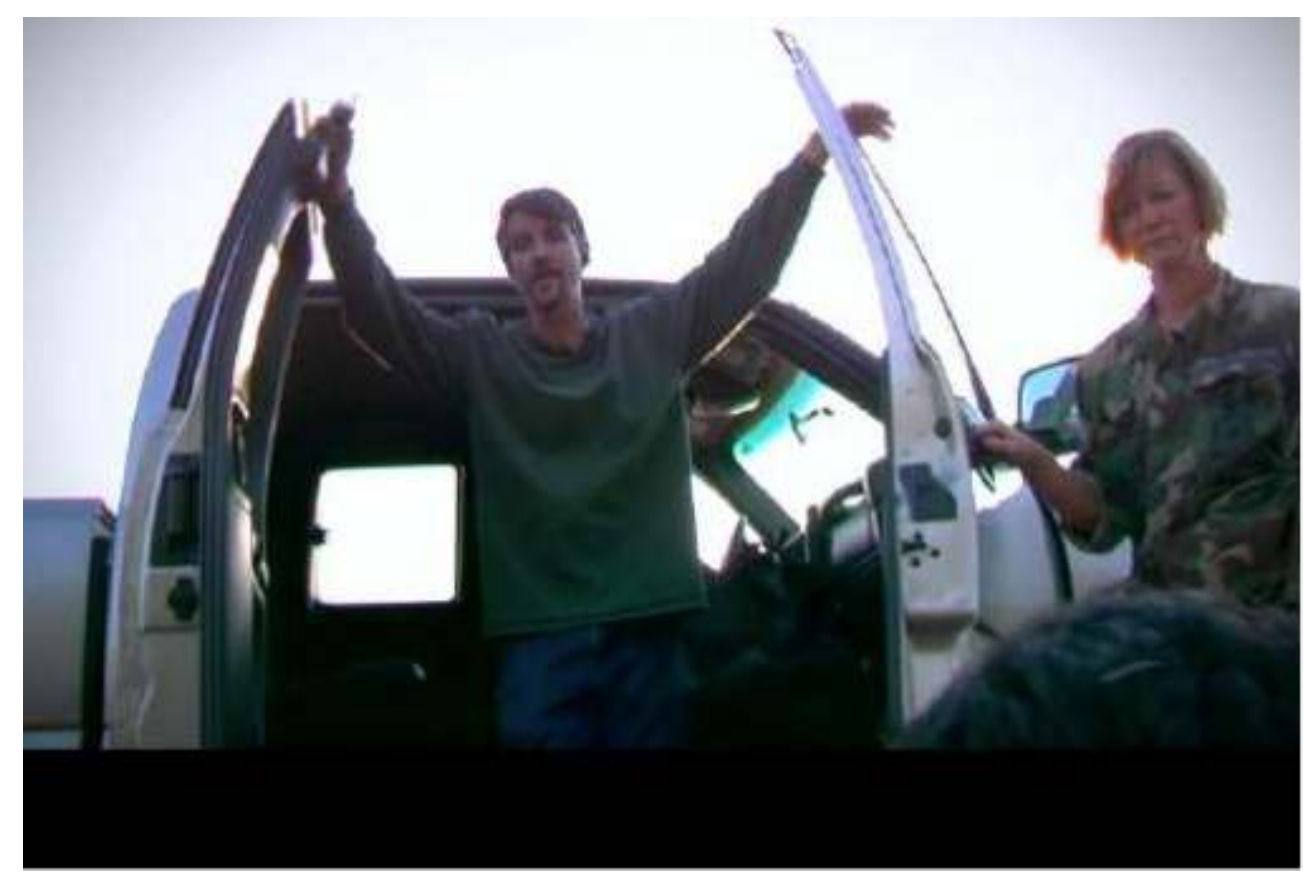

Al Otro Lado (Natalia Almada, 2005); screen captures

21 The documentaries not only try to elicit compassion for the migrants, they go against the dehumanization that is inherent in the Latino Threat Narrative. Indeed, Chavez identifies the tendency of talking about the immigrants as a mass, "devoid of the nuances and subtleties of real lived lives," and argues that it is dehumanization that turns them into invaders. ${ }^{47}$ The documentaries, on the contrary, take an interest in the individuals they follow, sometimes on each side of the border. In Al Otro Lado for instance, the film's protagonist, Magdiel, lives in Mexico, "on the other side" (as the title indicates), and the film highlights the reasons why he wants to immigrate to the United States. Magdiel is the perfect protagonist to bolster identification: he is friendly, talkative and gives insightful information about drug trafficking in his village. Natalia Almada even explains that she made him the protagonist because she wanted the audience "to feel what Magdiel felt." ${ }^{48}$ His testimony shows that the village of La Reforma in the state of Sinaloa in Mexico is devastated by poverty and that people need to find a way to survive, either by dealing drugs, smuggling migrants, or leaving. The film also portrays Magdiel as a talented young corrido singer whose morals have made him choose immigration rather than drug trafficking, even if he admits having a lot of powerful friends who try to lure him into the business with the money they make. ${ }^{49}$ The viewers are made to understand the additional ideological elements that influence young Mexicans, who are told from a young age that they can succeed in the United States. They are then enticed to believe that, in similar conditions, they would have made the same choices as Magdiel.

If, as Chavez says, the Latino Threat Narrative obscures the scientific data, the Latino Immigrant Rights Documentaries, on the contrary, shed light on it. Crossing Arizona puts the emphasis on the detrimental effects of the North American Free Trade Agreement (1994) on the Mexican economy, forcing people to leave the country because of the loss of sovereignty on their lands. Authoritative speakers, such as the legal activist Isabel Garcia, trace the responsibility to the United States ("It's something that we have actually created ourselves.") and explain the chain of events in simple terms: NAFTA 
pauperized Mexico and forced people to immigrate, which in turn forced the U.S. to militarize the border and turn it into a war zone. The information is presented as undeniable because the economic facts are presented either by people who are involved in the situation, whether they are Mexican farmers, people who live by the border and who have witnessed the increasing flow of immigrants, or by people whose jobs are to deal with the border issues. A whole new light is also shed on the traffic - of drugs and people - around the border: these activities appear as survival economies that have developed because of the collapse of the general economy, and because they generate tremendous amounts of money (coyotes usually ask for 2,000 dollars per migrant). Overall, the counterbalancing of the emotional content of the documentaries with economic facts portrays a situation that seems as complex as the number of people involved.

And yet, as Chavez explains, countering the Latino Threat Narrative means believing in a solution that lies "in political decisions made by governmental representatives," who, according to him, "could just as well have decided to allow migrants to enter under the sanction of law, as legal immigrants, legal workers, or legal guest workers." ${ }^{50} \mathrm{His}$ arguments are in keeping with the filmmakers' perspective shown in the four Latino Immigrant Rights Documentaries tackled here, especially in Crossing Arizona, whose last shot blames the U.S. government for believing in the Threat Narrative and not passing the immigration reform that has been pending for decades. With this last shot, the film leaves the viewers with the following to ponder on: "Despite strong public support for earned legalization, the U.S. Congress remains focused on criminalizing undocumented immigrants and increasing border enforcement." Even if this information is not complete (who gives strong support? how much support?), and the sources are not indicated, the quote illustrates the multidimensional strategies of the Latino Immigrant Rights Documentaries that combine the use of logical arguments (there is support), and the eliciting of an emotional reaction (indignation) that is linked to a moral judgment (the U.S. government does not do what it is supposed to do, which is what is morally right). Bruckman chooses to end his film differently: in the same building where Carmen was vacuuming, with the same outfit, he introduces Maria from the Dominican Republic, who could just as well have been the protagonist of his film. She might be a different immigrant; she probably has a similar story. While eco-documentaries, as Alexa Weik von Mossner explains, portray events as "consequential," the Latino Immigrant Rights Documentaries portray immigration as a continuum..$^{51}$ They make the case that, without proper measures, there will always be a never-ending flow of immigrants.

\section{Conclusion}

The study of the Latino Immigrant Rights Documentaries has shown that they deconstruct the Latino Threat Narrative by providing a counter-image of the stereotype of the dangerous disrespectful immigrants who will not assimilate. Additionally, they mobilize the wide range of emotions identified by Jonathan Haidt. Praising the immigrants, showing their suffering, condemning anti-immigration sentiment, and eliciting self-conscious thoughts in the viewership, they have the potential to "disrupt or redirect affects" towards a more compassionate understanding of the motivations surrounding immigration to the United States. ${ }^{52}$ 
to their limited distribution, mostly at film festivals, the films have not been reviewed widely by mainstream sources. Yet, the few reviews available show the range of reactions possible. Dennis Harvey from Variety praises Crossing Arizona's "engrossing" endeavor to show the issue from many points of view, as well as the filmmakers' efforts to feature non-stereotypical figures. However, Nathan Lee from the New York Times considers that the story of Magdiel from Al Otro Lado should have been told "in a different film." Thus, while one critic might have been convinced by the variety of emotions he felt while watching the film (sympathy for the ranchers, scorn towards the Minutemen and national Republican figures), another would have preferred to be only told about the "immigrant experience," and not that of an individual..$^{53}$ On a different note, Jesse Hawlish, for an online magazine, stresses the "raw emotions and moments of intimate family interactions" that, he argues, "would spur empathy from a stone." ${ }^{4}$ These different views touch upon the issue of "emotional habitus" developed by Cisneros and how it can affect one's viewing of a film. Thus, Cisneros' comments on the need to go "beyond visual and narrative strategies" in order to assess the impact of documentaries seems a necessary path to go beyond merely highlighting a complex problem but also solving it.

But if Latino Immigrant Rights Documentaries may not result in measurable or drastic change, they nevertheless represent a tendency in recent documentary filmmaking that responds to the decades of tensions surrounding immigration in the United States. What they actually do is participate in the public sphere and challenge the notion of "illegality" that Chavez argues has been constructed to decide who gets to enter and who is excluded. The documentaries advocate for an inclusive society in which each member is appreciated for their contributions. They suggest the redirection of the energy and money dedicated to border enforcement to a different way of handling immigration. Such a perspective exemplifies the intricate strategies at play in the Latino Immigrant Rights Documentaries to remind the viewers that the U.S. is a nation of immigrants.

\section{BIBLIOGRAPHY}

Al Otro Lado. Directed by Natalia Almada. 2005. United States: Altamura Films.

Austin, Thomas and Wilma de Jong eds. Rethinking Documentary. New Perspectives, New Practices. Berkshire: Open University Press, 2008.

Barnouw, Erik. Documentary, A History of Non-Fiction Film. New York and Oxford: Oxford University Press, 1993.

Bruzzi, Stella. New Documentary. New York: Routledge, 2006.

Chanan, Michael. The Politics of Documentary. London: British Film Institute, 2007.

Chavez, Leo R. The Latino Threat: Constructing Immigrants, Citizens, and the Nation. Stanford, California: Stanford University Press, 2013.

InMedia, 7.2. $\mid 2019$ 
Choi, Jinhee and Mattias Frey. Cine-ethics: Ethical Dimensions of Film Theory, Practice, and Spectatorship. New York: Routledge, 2014.

Cisneros, Josue David. “Affect, Emotion, and Immigration Rhetoric, or What Happens When a Minuteman Moves in With Undocumented Immigrants?" In The Rhetoric of US Immigration: Identity, Community, Otherness, edited by Johann Hartelius, 247-274. State College: Penn State Press, 2015.

Crossing Arizona. Directed by Dan DeVivo and Joseph Mathew. 2006. United States: Rainlake Productions.

DeChaine, Robert D., ed. Border Rhetorics: Citizenship and Identity on the US-Mexico Frontier. Tuscaloosa: University of Alabama Press, 2012.

Feng, Dezheng and Kay L. O'Halloran. “The Multimodal Representation of Emotion in Film: Integrating Cognitive and Semiotic Approaches”. Semiotica 2013, 197 (2013): 79-100. doi:10.1515/ sem-2013-0082.

Fitzsimmons, Stephen J. and Hobart G. Osburn. "The Impact of Social Issues and Public Affairs Television Documentaries". The Public Opinion Quarterly, Vol.32, No.3 (Autumn, 1968): 379-397.

Frau-Meigs, Divina. Socialisation des jeunes et éducation aux médias : du bon usage des contenus et comportements à risque. Paris: Éd. Érès CEMÉA, 2011.

Haidt, Jonathan. “The Emotional Dog and Its Rational Tail: A Social Intuitionist Approach to Moral Judgment." Psychological Review 108 No.4 (2001): 814-834.

Harvey, Dennis. “Crossing Arizona.” Variety. January 22, 2006. Accessed October 22, 2019. https:// variety.com/2006/film/markets-festivals/crossing-arizona-1200519175/

Hawlish, Jesse. "Point of Entry - Review." Slug Magazine. January 26, 2010. Accessed October 21, 2010. https://www.slugmag.com/festival-coverage/point-of-entry-review/

Hesford, Wendy S. "Documenting Violations: Rhetorical Witnessing and the Spectacle of Distant Suffering". Biography 27, 1 (2004): 104-144. https://hiplatina.com/natalia-almada-spotlightinterview/

HipLatina. "Filmmaker Natalia Almada Reflects on the Power of Latinas Uplifting One Another." July 17, 2017. Accessed October 21, 2019. https://hiplatina.com/natalia-almada-spotlightinterview/

La Americana. Directed by Nicholas Bruckman. 2008. United States: People's Television. https:// www.pressreader.com/philippines/philippine-daily-inquirer-1109/20100130/284021893192175

Lee, Nathan. “Music With a Message.” New York Times. March 1,2006. Accessed October 2, 2019. https://www.nytimes.com/2006/03/01/movies/music-with-a-message.html

Nepales, Ruben V. "Life Transformation in Fil-Am's Slamdance.” Philippines Daily Inquirer. January 30, 2010. Accessed October 21, 2019. https://www.pressreader.com/philippines/philippine-dailyinquirer-1109/20100130/284021893192175

Nichols, Bill. Introduction to Documentary. Indianapolis: Indiana university press, 2001.

Nichols, Bill. Representing Reality: Issues and Concepts in Documentary. Bloomington and Indianapolis: Indiana University Press,1991.

Nichols, Bill. Speaking Truths with Film: Evidence, Ethics, Politics in Documentary. Berkeley, California: University of California Press, 2016. 
O'Neill, Luke. “Advertisers Recoil as Tucker Carlson Says Immigrants Make the US 'Dirtier'." The Guardian. December 18, 2018. Accessed October 22, 2019. https://www.theguardian.com/media/ 2018/dec/18/tucker-carlson-immigrants-poorer-dirtier-advertisers-pull-out

Plantinga, Carl. Screen Stories: Emotion and the Ethics of Engagement. Oxford: Oxford University Press, 2018.

Point of Entry. Directed by Zeus Quijano Jr. 2009. United States. https://www.youtube.com/watch? v=LZqQfW9zwiI

Youtube. POV channel. "Al Otro Lado (To The Other Side) - Natalia Almada - Behind the Lens - POV | PBS”. October 29, 2015. Accessed October 21, 2019. https://www.youtube.com/watch? v=LZqQfW9zwiI

Radford, Jynnah and Luis Noe-Bustamante. “Facts on U.S. Immigrants, 2017.” Pew Research Center. June 3, 2019. Accessed October 22, 2019. https://www.pewresearch.org/hispanic/ 2019/06/03/facts-on-u-s-immigrants/

Radford, Jynnah and Luis Noe-Bustamante. "Origins of the U.S. immigrant population, 1960-2017.” Pew Research Center. September 18, 2017. Accessed September 1, 2019. https:// www.pewresearch.org/hispanic/2019/06/03/facts-on-u-s-immigrants/.

Weik von Mossner, Alexa. Moving Environments: Affect, Emotion, Ecology, and Film. Waterloo, Ont.: Wilfrid Laurier University Press, 2014.

\section{ENDNOTES}

1. Leo R. Chavez, The Latino Threat: Constructing Immigrants, Citizens, and the Nation. Stanford, California:

Stanford University Press, 2013.

2. In this article, the word "Latino" refers to the individuals of Latin American descent who have immigrated

to the United States or were born there, and whether they are documented or not.

3. The Treaty of Guadalupe-Hidalgo (1848) stipulated that the USA must pay Mexico $\$ 15 \mathrm{M}$ in exchange for ownership of a large area of land that would become the states of Arizona, California, Colorado, Utah and half of New Mexico

4. Luke O'Neill, "Advertisers Recoil as Tucker Carlson Says Immigrants Make the US 'Dirtier'," The Guardian. December 18, 2018, accessed October 22, 2019, https://www.theguardian.com/ media/2018/dec/18/tucker-carlson-immigrants-poorer-dirtier-advertisers-pull-out

5. Chavez, The Latino Threat, 59.

6. Jynnah Radford and Luis Noe-Bustamante, "Origins of the U.S. immigrant population, 1960-2017," Pew Research Center, September 19, 2017, accessed September 1, 2019, . https:// www.pewresearch.org/hispanic/2019/06/03/facts-on-u-s-immigrants/

7. Jynnah Radford and Luis Noe-Bustamante, "Facts on U.S. Immigrants, 2017," Pew Research Center, June 3, 2019, accessed October 22, 2019, https://www.pewresearch.org/hispanic/ 2019/06/03/facts-on-u-s-

8. Anne Teresa Demo, “Decriminalizing Illegal Immigration: Immigrants' Rights through the Documentary Lens", in Border Rhetorics, ed. DeChaine et al., 197-212.

9. Demo, Decriminalizing Illegal Immigration,197.

10. Carl Plantinga. Screen Stories: Emotion and the Ethics of Engagement. Oxford: Oxford University Press, 2018. Even if most of Plantiga's comments pertain to fiction film, he uses the term "screen stories" which leads the way to the use of his remarks on documentary film as well. 
11. Josue David Cisneros, "Affect, Emotion, and Immigration Rhetoric, or What Happens When a Minuteman Moves in With Undocumented Immigrants?" in The Rhetoric of US Immigration: Identity, Community, Otherness, ed. Johann Hartelius (State College: Penn State Press, 2015), 247-274.

12. Cisneros, "Affect, Emotion, and Immigration Rhetoric," 248.

13. Ibid, 252.

14. Except for Al Otro Lado, which is a co-production between Mexico and the United States, the documentaries were all produced and released in the United States.

15. Chavez, The Latino Threat, 213.

16. Bill Nichols, Introduction to Documentary (Indianapolis: Indiana University Press, 2001), 2.

17. Weik von Mossner, "Emotions of Consequence?", 46.

18. Weik von Mossner, "Introduction," 1.

19. Michael Chanan, The Politics of Documentary (London: British Film Institute, 2007), vi.

20. Plantinga, Screen Stories, 107.

21. Bill Nichols, Representing Reality: Issues and Concepts in Documentary (Bloomington and Indianapolis: Indiana University Press, 1991), 107.

22. Demo, "Decriminalizing Illegal Immigration," 199.

23. Weik von Mossner, "Emotions of Consequence?," 53.

24. The Comprehensive Immigration Reform Act of 2007, or Secure Borders, Economic Opportunity and Immigration Reform Act of 2007, was introduced in the $110^{\text {th }}$ Congress during George Bush's presidency. It provided a path to citizenship to 12 million undocumented immigrants while enforcing border security.

25. Annette Hill, "Documentary Modes of Engagement," in Rethinking Documentary: New Perspectives, New Practices, eds. Thomas Austin and Wilma de Jong (Berkshire : Open University Press. 2008), 217.

26. In Latin America, the quinceañera is a party that celebrates a girl's fifteenth birthday and her passage from childhood to womanhood.

27. "You have to lie and you have to walk, and you have to risk your life to cross and to come here. You have to put yourself in debt. You have to leave behind all your family, all the things you love, your house, your belongings, your pets, your children, your mother..." (translated by the author). The film provides English subtitles whenever a person speaks Spanish.

28. Plantinga, Screen Stories, 44.

29. “[...] Give me your tired, your poor,/Your huddled masses yearning to breathe free,/The wretched refuse of your teeming shore./Send these, the homeless, tempest-tost to me,/I lift my lamp beside the golden door!". Emma Lazarus, The New Colossus. 1883.

30. Plantinga, Screen Stories, 45.

31. Plantinga, Screen Stories, 35.

32. Feng, Dezheng, and Kay L. O'Halloran. "The multimodal representation of emotion in film: Integrating cognitive and semiotic approaches." Semiotica 2013, 197 (2013): 82. doi:10.1515/ sem-2013-0082.

33. Feng and O'Halloran, "The multimodal representation of emotion in film," 82 . This process is used in numerous documentaries about the border, so much so that the former director of Cine Las Americas, the festival in Austin, has said that the festival was once referred to as a "tearjerking film festival". See Eugenio Del Bosque and Emilie Cheyroux, «Latino images in Austin, Texas », InMedia [Online], 3 | 2013, Online since April 22, 2013, accessed October 25 2019. URL : http://inmedia.revues.org/580

34. Weik von Mossner, "Introduction," 3.

35. Plantinga, Screen Stories, 57.

36. In the spring of 2006, immigrant marches and demonstrations began as a response to HR4437 (Border Protection, Anti-Terrorism and Illegal Control Act of 2005), a bill passed by the House of 
Representatives in December 2005 (but not by the Senate) in order to reinforce border security, and raise penalties for undocumented immigrants and for those who helped them. In March, the "Gran Marcha" protest held in Los Angeles gathered 500,000 people. The demonstrations caused controversy because some participants (mostly students) waved Mexican flags, which was perceived as a sign of rebellion and invasion by anti-immigrant groups. Immigrants, on the other hand, argued that showing pride in your roots does not mean disloyalty to the United States.

37. Jonathan Haidt, "The Emotional Dog and Its Rational Tail: A Social Intuitionist Approach to Moral Judgment," Psychological Review, 108 No.4 (2001): 814-834.

38. Demo, "Decriminalizing Illegal Immigration," 205.

39. Ibid

40. Ibid

41. Chavez, The Latino Threat, 139.

42. Ibid, 5 .

43. Crossing Arizona (Dan DeVivo and Joseph Mathew, 2006).

44. Even years after the films were released, such statements are reminiscent of the rants about immigrants creating an unsafe and "dirtier" country, be it Donald Trump during his well-known presidential campaign speech in 2015 in which he associated all immigrants with "rapists" and "criminals," or Tucker Carlson on Fox News in 2019.

45. Plantinga, Screen Stories, 43.

46. Demo, "Decriminalizing Illegal Immigration," 206.

47. Chavez, The Latino Threat, 6 .

48. "Al Otro Lado (To The Other Side) - Natalia Almada - Behind the Lens - POV | PBS," Youtube. POV channel, October 29, 2015, Accessed October 21, 2019, https://www.youtube.com/watch? $\mathrm{v}=\mathrm{LZqQfW} 9 \mathrm{zwiI}$

49. Corridos are traditional Mexican songs that talk about real life experiences. In the documentary, Almada dwells on its cultural meaning in Mexico, especially the sub-category of the narco-corridos that celebrate the fame of certain drug dealers.

50. Chavez, The Latino Threat, 27.

51. Weik von Mossner, "Emotions of Consequence," 41.

52. Cisneros, "Affect, Emotion, and Immigration Rhetoric," 252.

53. Nathan Lee, "Music With a Message," New York Times, March 1, 2006, Accessed October 2, 2019, https://www.nytimes.com/2006/03/01/movies/music-with-a-message.html

54. Jesse Hawlish, "Point of Entry - Review," Slug Magazine, January 26, 2010, Accessed October 21, 2010, https://www.slugmag.com/festival-coverage/point-of-entry-review/

\section{ABSTRACTS}

This article analyzes the way Immigrant Rights Documentaries elicit emotion in order to engage the viewers. "Engagement theory," developed by C. Plantinga, is used to shed light on the cognitive but also affecting processes at work in these films. Four documentaries, released between 2005 and 2009, are scrutinized: La Americana (Nicholas Bruckman, 2008), Point of Entry (Zeus Quijano Jr, 2009), Al Otro Lado (Natalia Almada, 2005) and Crossing Arizona (Dan DeVivo and Joseph Mathew, 2006). Since these films exclusively involve Latino immigrants who crossed the US-Mexico border without authorization, the study will focus on the way emotional engagement can contribute to counteracting the Latino Threat Narrative (Leo R. Chavez) that portrays Latino immigrants as "aliens" coming to invade the U.S. 
INDEX

Keywords: immigrant rights documentaries, Latino threat narrative, engagement theory, immigration in the United States

\section{AUTHOR}

\section{EMILIE CHEYROUX}

Emilie Cheyroux holds a PhD in American Studies from the University of Paris 3 Sorbonne Nouvelle. Her dissertation dealt with a Latino film festival's strategies to deconstruct stereotypes about Latinos in the United States, and more particularly in the city of Austin, Texas. Her research took into account the analysis of the festival's program as well as its local impact and networking strategies. 